\title{
Bilateral parameatal cysts with associated hypospadias presenting in a newborn baby
}

\author{
Sebastian Brown, Ahmed Salah Ahmed Mohamed, Sagarika Ray, Shiva Shankar
}

Department of Neonatal Medicine, The Shrewsbury and Telford Hospital NHS Trust, Telford, UK

\section{Correspondence to} Dr Sagarika Ray, sagarika.ray@nhs.net

Accepted 20 September 2018

Check for updates

(c) BMJ Publishing Group Limited 2018. No commercial re-use. See rights and permissions. Published by BMJ.

\begin{tabular}{l}
\hline To cite: Brown S, \\
Mohamed ASA, Ray S, et al. \\
BMJ Case Rep Published \\
Online First: [please \\
include Day Month Year]. \\
doi:10.1136/bcr-2018- \\
227425 \\
\hline
\end{tabular}

\section{DESCRIPTION}

A male infant presented to the neonatal team on day 1 of life with concerns over cysts on his penis. He had been born at term in good condition following an emergency caesarean section for face presentation and suboptimal cardiotocograph. There was no relevant antenatal history of note and no significant family history.

He had a normal examination other than his genitalia. He had a coronal hypospadias with two symmetrical cystic lesions measuring 2-3 mm each on the glans penis, just distal and lateral to the opening of the urethral meatus on the ventral surface (figure 1). There was no obvious discharge or surrounding erythema. By day 2, there was some mild superficial ulceration of the cyst surfaces. Both testes were palpable in his scrotum. He was discharged home after confirmation of a good urinary stream.

The cysts had started to resolve spontaneously by day 4 of life and a review at 3 weeks of age revealed minimal 'pin-prick' sized bilateral residual ulceration visible on the glans. They were clinically confirmed as parameatal urethral cysts by the urosurgeon.

Parameatal urethral cysts have been described in the literature, and genital abnormalities are not typically encountered. However, this infant presented with bilateral parameatal cysts and a hypospadias.

Parameatal urethral cysts are rare congenital penile lesions, of which only around 50 cases have been reported in the literature. ${ }^{12}$ Although more common in males, it can also present in females. Presentation in the paediatric population is less common and is usually after infancy. It is a benign condition which is generally not associated with any other congenital anomalies, although we describe bilateral lesions in the context of a hypospadias. A physical examination is sufficient to confirm the clinical diagnosis. Spontaneous resolution has been described, possibly more common in younger children, ${ }^{3}$ but the mainstay of treatment remains complete surgical excision, due to the risk of recurrence with aspiration, de-roofing or marsupialisation. ${ }^{3}$ Complete surgical excision carries minimal morbidity with minimal chance of recurrence and excellent cosmetic results.

Various theories have been proposed for their pathogenesis, ranging from residual effects of preputial delamination, to occlusion of the paraurethral ducts, or anomalous urethral fusion. They have been proposed to be variants of median raphe cysts. $^{23}$ Histological analyses suggest they may arise from transitional, cuboidal, columnar or squamous epithelial cells or indeed a combination of these. ${ }^{3}$ Sizes have been reported to be typically less than $1 \mathrm{~cm}$

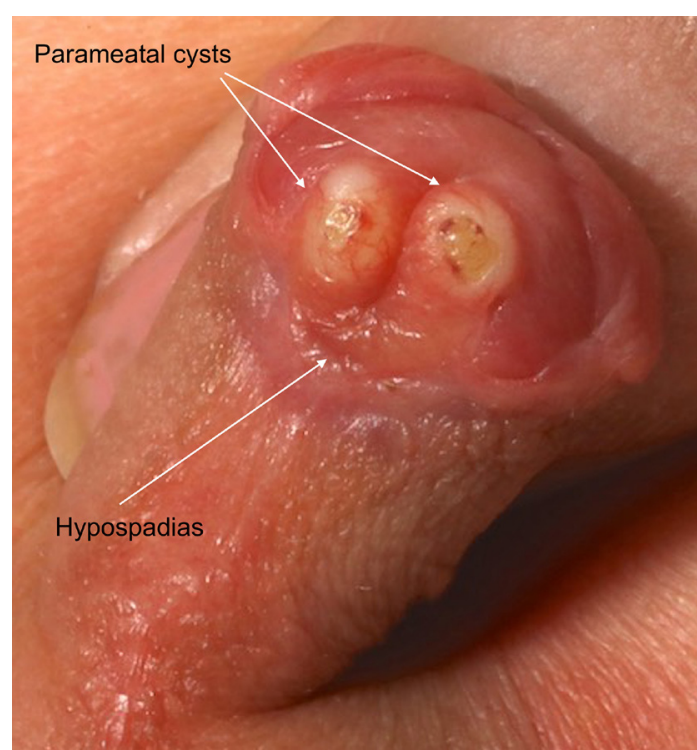

Figure 1 Male genitalia demonstrating two parameatal urethral cysts and coronal hypospadias.

in prepubertal males. While the lesions themselves are benign and typically asymptomatic, complications may include disruption of the urinary stream; discomfort on micturition; or, in older patients, painful sexual intercourse and cosmetic concerns. ${ }^{3}$

Our case is unusual as the presentation was in the newborn period, along with other urogenital anomalies. This supports the role for conservative management in neonatal presentations, after careful assessment to ensure unobstructed micturition. Surgical management should be reserved for lesions that do not resolve or which become symptomatic.

\section{Learning points}

It is important to consider the possibility of parameatal urethral cysts in neonates presenting with cystic lesions over the genitalia. They generally have a benign natural course and most tend to resolve spontaneously. They are rarely associated with other abnormalities.

- It is important to monitor for good urinary stream to ensure that there is no mechanical obstruction due to the parameatal cysts. If any concerns or persistence of the cysts beyond 6 months, urological opinion for surgical excision is required.

Contributors SR and SS identified the case. SB and ASAM undertook the literature search and drafted the manuscript. SR and SS reviewed and revised the manuscript. SB, ASAM, SR and SS approved the final manuscript. 
Funding The authors have not declared a specific grant for this research from any funding agency in the public, commercial or not-for-profit sectors.

Competing interests None declared.

Patient consent Parental/guardian consent obtained.

Provenance and peer review Not commissioned; externally peer reviewed.

\section{REFERENCES}

1 Kaselas C, Spyridakis I, Patoulias D, et al. Parameatal urethral cyst in a newborn-a case report and review of the literature. I Clin Diagn Res 2016;10:SD01-2.

2 S L, Ankur A. Parameatal cyst: a presentation of rare case and review of literature. I Clin Diagn Res 2013;7:1757-8

3 Willis HL, Snow BW, Cartwright PC, et al. Parameatal urethral cysts in prepubertal males. J Urol 2011;185:1042-5.

Copyright 2018 BMJ Publishing Group. All rights reserved. For permission to reuse any of this content visit http://group.bmj.com/group/rights-licensing/permissions.

BMJ Case Report Fellows may re-use this article for personal use and teaching without any further permission.

Become a Fellow of BMJ Case Reports today and you can:

- Submit as many cases as you like

- Enjoy fast sympathetic peer review and rapid publication of accepted articles

Access all the published articles

Re-use any of the published material for personal use and teaching without further permission

For information on Institutional Fellowships contact consortiasales@bmjgroup.com

Visit casereports.bmj.com for more articles like this and to become a Fellow 